\title{
Pancreatic exocrine function after truncal and highly selective vagotomy
}

\author{
DP MIKHAILIDIS, Y FOO, L RAMDIAL, RM KIRK, * SB ROSALKI, P DANDONA \\ From the Department of Chemical Pathology, and the *Department of Surgery, Royal Free Hospital, \\ Pond Street, London NW3 2QG
}

SUMMARY We have measured plasma glucose and immunoreactive trypsin concentrations and serum pancreatic amylase activities in single blood samples following truncal vagotomy (TV) in 13 patients and highly selective vagotomy (HSV) in 14 patients. Our results show that an increased incidence of exocrine pancreatic insufficiency occurs postoperatively regardless of the type of vagotomy. Glucose concentrations were significantly higher after TV, suggesting that HSV is preferable for patients at risk of or suffering from diabetes mellitus.

Reduction of gastric acid secretion by section of the vagal nerve supply of the stomach (vagotomy) is widely used in the treatment of duodenal ulcer. The vagus innervates both the stomach and the pancreas. Section of both vagal trunks, truncal vagotomy (TV), in addition to reducing gastric acid, may also impair both endocrine and exocrine pancreatic function, as shown by reduced insulin, ${ }^{1}$ glucagon ${ }^{1}$ and pancreatic polypeptide, ${ }^{2}$ and abnormal duodenal enzyme release. ${ }^{3}$ Selective vagotomy (SV), and highly selective vagotomy (HSV) which unlike TV, preserve the vagal nerve supply to the pancreas, cause less impairment of pancreatic function. ${ }^{1-3}$ We have compared pancreatic function in post-TV and post-HSV patients using recently developed laboratory methods which allow the specific measurement in serum of enzymes of pancreatic origin and permit the noninvasive assessment of pancreatic exocrine function.

\section{Material and methods}

Twenty-seven postvagotomy patients were studied. Operations were performed by several surgeons over a period of two years. Patients with conditions known to affect pancreatic function (including diabetes mellitus, pancreatitis, or clinical or radiological evidence of gallstones) were excluded. All patients were asymptomatic. The type of vagotomy, age and sex composition of the patients, and the time elapsed postoperatively at sampling are shown in Table 1 .

Pancreatic exocrine function was assessed by the determination of serum immunoreactive trypsin

Accepted for publication 18 February 1981
Table 1 Characteristics of patients included in the study

\begin{tabular}{lll}
\hline & $\begin{array}{l}\text { Truncal } \\
\text { vagotomy }\end{array}$ & $\begin{array}{l}\text { Highly selective } \\
\text { vagotomy }\end{array}$ \\
\hline Number of patients & 13 & 14 \\
$\quad$ Males & 11 & 10 \\
Females & 2 & 4 \\
Mean age \pm SD & $62 \pm 12$ & $49 \pm 13$ \\
$\begin{array}{l}\text { Age range (yr) } \\
\text { Time elapsed postoperatively } \\
\text { before sampling (months } \pm \text { SD) }\end{array}$ & $43-78$ & $36-69$ \\
\hline
\end{tabular}

(SIRT) and serum pancreatic isoamylase (SPA) activity in a single fasting postoperative sample. Patients were fasted overnight and blood samples were collected between 9 and $10 \mathrm{am}$. A fasting glucose concentration was also measured to assist in the exclusion of diabetes. Serum was separated and stored at $-20^{\circ} \mathrm{C}$ until analysis, which was generally carried out within one week of sampling. Plasma glucose was estimated on the morning of sampling using the Beckman glucose analyser (glucose oxidaseoxygen electrode method). No patient had fasting glucose values less than $3.3(59.4 \mathrm{mg} / 100 \mathrm{ml})$ or greater than $5.2 \mathrm{mmol} / 1(93.7 \mathrm{mg} / 100 \mathrm{ml})$. SIRT and SPA were determined by methods previously described. ${ }^{4}{ }^{5}$ Statistical comparisons were carried out using Students' unpaired $t$ test and the $\chi^{2}$ test (with Yates' correction). Reference ranges were obtained by testing normal healthy volunteers ( 96 subjects for SIRT, 97 subjects for SPA values).

\section{Results}

The number of patients with low SPA values was 963 
significantly greater $\left(\chi^{2}: \mathrm{p}<0.01\right)$ when both patient groups (TV and HSV) were considered together and compared with the controls (Table 2). There was no significant difference observed when the TV and HSV groups were compared individually with the controls. Similar comparisons for SIRT showed no significant differences.

Table 2 Subnormal (that is, mean - 2SD) SPA and SIRT values in TV and HSV groups and in controls

\begin{tabular}{lll}
\hline & $\begin{array}{l}\text { Serum immunoreactive } \\
\text { trypsin }\end{array}$ & $\begin{array}{l}\text { Serum pancreatic } \\
\text { isoamylase }\end{array}$ \\
\hline $\begin{array}{lll}\text { Patients } \\
\text { Truncal vagotomy }\end{array}$ & $1 / 13$ & \\
Highly selective & & $3 / 13$ \\
$\quad$ vagotomy & $0 / 14$ & $2 / 14$ \\
Both & $1 / 27$ & $5 / 27^{*}$ \\
Controls & $0 / 96$ & $2 / 97$ \\
\hline
\end{tabular}

*Patients $v$ controls $\mathrm{p}<0.01$.

There were no significant differences in mean SIRT and SPA values when the two vagotomy groups were compared using Student's $t$ test (Table 3). However, the mean fasting glucose values were significantly higher in the TV group $(p=0.02)$.

Table 3 Comparison of mean SIRT concentrations, amylase activities, and glucose concentrations in the two vagotomy groups

\begin{tabular}{|c|c|c|c|}
\hline Test & $T V( \pm S D)$ & $H S V( \pm S D)$ & $\begin{array}{l}\text { p value } \\
(T V \vee H S V)\end{array}$ \\
\hline \multicolumn{4}{|l|}{ Amylase } \\
\hline $\begin{array}{l}\text { Total amylase (ref range: } \\
209 \pm 52 \mathrm{IU} / 1 \text { at } 37^{\circ} \mathrm{C} \text { ) }\end{array}$ & $227(72)$ & $232(72)$ & NS \\
\hline $\begin{array}{l}\text { range: } 115 \pm 27 \mathrm{IU} / \mathrm{l}) \\
\text { SIRT }(249 \pm 51 \mu \mathrm{g} / \mathrm{l}) \\
\text { Glucose }(3-5 \mathrm{mmol} / \mathrm{l}) \dagger\end{array}$ & $\begin{array}{l}115(67) \\
277(118) \\
4 \cdot 8(0 \cdot 3)\end{array}$ & $\begin{array}{l}107(33) \\
241(49) \\
4 \cdot 4(0 \cdot 5)\end{array}$ & $\begin{array}{l}\text { NS } \\
\text { NS } \\
0.02\end{array}$ \\
\hline
\end{tabular}

†Reference range at Royal Free Hospital.

NS = not significant.

\section{Discussion}

The prevalence of subnormal SPA values in the postvagotomy patients as a whole was significantly higher than expected. When each group was separately compared with controls, no significant differences were observed, probably because of the small numbers in each patient group. These results suggest that some degree of pancreatic exocrine impairment does occur after vagotomy, even if the operation was a HSV. This may be due to variation in surgical technique with resulting damage to the pancreatic vagal supply or to a mechanism not involving the vagal supply.

Mean plasma glucose values were significantly different in the two patient groups, glucose concentrations being higher after TV than after HSV. This finding is consistent with previous work ${ }^{1}$ reporting impaired insulin release following interruption of the vagal nerve supply to the pancreas.

The TV group underwent a drainage procedure (pyloroplasty) whereas the HSV group did not. Such a procedure might affect gastrointestinal transit time and release of various gastrointestinal hormones thus influencing insulin response and other pancreatic function. Furthermore, vagal denervation of the gut may render it hypersensitive to physical and chemical stimuli. ${ }^{6}$ Thus the observed changes cannot, with confidence, be solely ascribed to the effect of vagotomy on the pancreas.

The tests we have examined were of no value in providing an index of the completeness of vagotomy. Although mean values of glucose differed significantly in both patient groups, there was considerable overlap. There was also considerable overlap when the SPA and SIRT values were similarly compared. Perhaps better discrimination could be achieved if pre- and postoperative samples were compared.

Our finding of significantly higher mean glucose values, together with the previously reported impairment of insulin release ${ }^{1}$ in patients who had undergone TV, and the absence of these effects after HSV suggests that the latter is preferable for patients suffering from or likely to develop diabetes.

\section{References}

${ }^{1}$ Russell RCG, Thomson JPS, Bloom SR. The effect of truncal and selective vagotomy on the release of pancreatic glucagon, insulin, and enteroglucagon. Br J Surg $1974 ; 61: 821-4$.

${ }^{2}$ Stern AI, Hansky J, Korman MG, Coupland G, Waugh J. Pancreatic polypeptide. Release following surgery for duodenal ulcer disease. Dig Dis Sci 1980;25:485-8.

${ }^{3}$ McKelvey STD, Toner D, Connell AM, Kennedy TL. Coeliac and hepatic nerve function following selective vagotomy. Br J Surg 1973;60:219-21.

${ }^{4}$ Foo Y, Rosalki SB, Ramdial L, Mikhailidis D, Dandona P. Serum isoamylase activities in diabetes mellitus. $J$ Clin Pathol 1980;33:1102-5.

${ }^{5}$ Dandona P, Elias E, Beckett AG. Serum trypsin concentrations in diabetes mellitus. $\mathrm{Br}$ Med J 1978;ii :1125-7.

- Guttierrez LV, Kocak N, Cox AG. Alimentary transit and supersensitivity after vagotomy in the rat. Gut $1971 ; 12$ : $625-8$.

Requests for reprints to: Dr DP Mikhailidis, Department of Chemical Pathology, Royal Free Hospital, London NW3 2QG, England. 